ELK

Asia Pacific Journals

www.elkjournals.com

\title{
STUDY OF INDUSTRY COMPETITION IN VARIOUS STAGES OF THE INDUSTRY LIFE-CYCLE
}

\author{
Nabanita Sengupta \\ Chartered Accountant and B.Com (Hons) from University of Calcutta \\ nabanita.nsg@gmail.com
}

\begin{abstract}
Industry life-cycle is a concept which proposes that almost all industries progress through a predictable life-cycle, wherein, newly formed industries are fragmented, and consolidate as they progress and then mature with time and ultimately decline. The degree of competition being faced by a firm in an industry changes as an industry progresses through its life-cycle and the appropriate use of specific business strategies depends largely on the phase of the life-cycle of the industry in which the firm operates. The purpose of this paper is to understand the different stages of the industry life-cycle and study the changing nature of competition that prevails in each stage, analysing how the same impacts the survival strategies adopted by firms. The author familiarizes the readers with the concept of the industry life-cycle and the various forces which influence industry competition. Thereafter, the author carries out a detailed study of sample industries in the Indian economy which are in various stages of their life-cycle and analyses the competition prevailing among the industry players in each stage. The paper presents, through examples, the impact that the changing nature of industry competition has on the survival strategies adopted by firms in each stage of the industry life cycle. The paper concludes with the notion that business strategies of firms vary depending upon the corresponding stage of the industry life cycle, wherein, each phase requires a different approach to industry competition to ensure the existence and growth of the firm.
\end{abstract}

Keywords: Industry competition, Industry life cycle, Porter's Competition Framework

\section{INTRODUCTION}

The 'Industry life-cycle' concept states that almost all industries progress through a predictable life-cycle which consists of various stages. The degree of competition being faced by a firm in an industry changes as an industry progresses through its life-
Cycle and understanding where in the cycle an industry is largely influences the strategies adopted by the firm to face competition and survive in the long-run.

CONCEPT OF INDUSTRY LIFECYCLE 
The Abernathy/Utterback model [1] introduced in 1979 states that based on the level of innovation, industries move through three phases: Fluid Phase (characterized by product innovations), Transitional Phase (characterized by process innovations) and Specific Phase (characterized by incremental innovations). Although, this model does not hold good for all industries, the product-process model has further evolved into the widely accepted concept of industry life cycle which proposes that industries start small in their development stage, then go through a period of rapid growth, after which the rate of growth slows, and the industry enters the shakeout stage. The final two stages are first a period of slow or even zero growth of maturity, before the final stage of decline[2] (Refer Fig. 1).

\section{PORTER'S 5-FORCES COMPETITION FRAMEWORK}

Introduced by Michael Porter in 1979[3], the Five Forces Competition Framework shows how the structure of an industry determines the degree of competition within the industry and as such, the level of profitability (or attractiveness) of the industry. Porter's five forces include three forces from 'horizontal' competition namely, the threat of substitute products or services, the threat of established rivals, and the threat of new entrants and two others from 'vertical' competition namely, the bargaining power of suppliers and the bargaining power of customers (Refer Fig. 2).

Porter proposed that the power of the five forces typically vary as an industry moves through various stages of its life cycle. This paper seeks to examine various industries in the Indian economy which are in different stages of their life cycle and study the nature of competition prevailing in these industries so as to understand the implications that the five-forces of industry competition have on survival strategies in each stage of the industry life cycle.

\section{DEVELOPMENT STAGE OF THE INDUSTRY LIFE CYCLE}

The first stage generally begins with a few start-ups just immerging from a newly deregulated or privatized industry. However, the concentration of market share among a few players quickly gets diluted as competitors arise and the industry gets fragmented into several small players with the 3 largest players typically holding 10\% 


\section{ELK ASIA PACIFIC JOURNAL OF FINANCE AND RISK MANAGEMENT}

ISSN 2349-2325 (Online); DOI: 10.16962/EAPJFRM/issn. 2349-2325/2015; Volume 9 Issue 3 (2018)

to $30 \%$ of the total market share [4]. The influence of the five forces are likely to be weak as there is little direct rivalry among the firms, although, profits may remain low due high investment requirements [2].

This has been witnessed by the pharmaceutical industry in India which has seen a drastic change in its structure since India's accession to World Trade Organization (WTO) and its obligation to implement Trade Related Aspects of Intellectual Property Rights (TRIPS). Earlier, under the Indian Patents Act, 1970, only process-related patents were granted on inventions, which had resulted in players reducing their focus on $R \& D$ and instead concentrate on duplicating existing products by developing the same drugs with a slightly or substantial different process. With the implementation of the Patents (Amendment) Act, 2005 to meet India's obligations under TRIPS, the industry had to adopt product patent in all fields of technology which opened up opportunities for the industry in terms of investment in $R \& D$. The Indian pharma sector has since witnessed the emergence of numerous players, with the "organized" sector of the industry consists of 250 to 300 companies, which account for around 70\% of products on the market with the top 10 firms representing $30 \%$. However, the total sector is estimated at nearly 20,000 businesses, some of which are extremely small[5]. Control over market share remains distributed over various players with the largest player, Sun Pharma holding only about $8.5 \%$ market share in the over Rs. 119,000 crore Indian pharmaceutical market as on March 2018[6]. Typical to industries in the development stage, the pharma industry is characterized by significant investment spending - with the total $R \& D$ expenditure for the top five Indian pharma companies increasing sixfold since FY10 to a record Rs. 8,025 crore in FY17[7]. The industry is gradually preparing itself for transition into the 'growth phase' of its life cycle with industry registering a growth of $9.5 \%$ in market sales in March 2018 as against 8\% in March 2016[8].

\section{GROWTH STAGE OF THE INDUSTRY LIFE CYCLE}

With the emergence of new technologies in the development phase, the cost of the product is reduced, quality starts improving, demand starts increasing and the industry enters the growth phase of its life cycle. Products are differentiated in terms of their technology, performance and reliability. 


\section{ELK ASIA PACIFIC JOURNAL OF FINANCE AND RISK MANAGEMENT}

ISSN 2349-2325 (Online); DOI: 10.16962/EAPJIFRM/issn. 2349-2325/2015; Volume 9 Issue 3 (2018)

Investments remain high, yet now in a smaller percentage than in the introduction phase and there is a transition to mass production [9]. Porter's five-forces begin to show their influence as low barriers to entry increase threat of new entrants and substitutes begin flooding the market. Growing awareness about the products increase bargaining power of customers and reduce brand loyalty. This is a stage in which businesses rapidly build up scale and major players begin to emerge. Top 3 players rapidly capture around $15 \%$ to $45 \%$ of the market as the industry starts preparing itself for consolidation [4].

The smartphone industry in India exhibits features of an industry going through its growth phase with the emergence of several major players who compete directly with each other for market share and are significantly focused on product differentiation in terms of technology and quality so as to acquire and retain customers. Rapid growth of the Indian smartphone market in its development stage had helped nurture a crop of local brands, led by Micromax which held a 14\% market share at the end of FY15 and stood second only to Samsung which had held around 26\%[10]. However, the rapid smartphone penetration in India and the potential to become the second largest mobile market in the world after China with its population of 1.3 billion, has caused several Chinese manufacturers to enter the Indian market with their own brands - depressing prices and hurling the industry into an aggressive growth stage. While some Chinese brands such as Xiaomi, Oppo, Vivo and Gionee have rapidly captured market share by giving higher margins to retailers and higher payments for display space and branding in stores, others like Xiaomi and Lenovo have adopted significant innovation and product differentiation to gain customer base. As competition has intensified, Samsung has been fighting to retain its top spot through development of low cost smartphones and heavy marketing spends. However, market shares of local brands such as Micromax and Karbonn have been shrinking rapidly due to lack of innovation and extensive presence of lower cost/higher performing substitutes in the market[11]. The face of the Indian smartphone industry has changed significantly over the period between 2015 to Q2 2018 with the relatively new entrant Xiaomi having caught up with the previous market leader Samsung - each holding a market share of $28 \%$, followed closely by Vivo at $12 \%$ and Oppo at 9\% in Q2 2018 [10]. The growth 


\section{ELK ASIA PACIFIC JOURNAL OF FINANCE AND RISK MANAGEMENT}

ISSN 2349-2325 (Online); DOI: 10.16962/EAPJFRM/issn. 2349-2325/2015; Volume 9 Issue 3 (2018)

stage in the Indian smartphone industry is gradually bringing forth the winners in the race to acquire scale and market share, and as such, is resulting in the emergence of losers; signaling that the industry will now begin positioning itself for later rounds of consolidation that will yield the industry giants.

\section{SHAKE-OUT (CONSOLIDATION) STAGE OF THE INDUSTRY LIFE CYCLE}

'Shakeout' is a term used to describe the consolidation of an industry or sector, in which businesses are eliminated or acquired through competition [12]. This stage occurs at the end of the growth stage when Porter's five-forces have gained considerable momentum and begin exerting their maximum influence on industry competition. Buyers command considerable bargaining power and industry players are forced to cut prices to retain existing customers and counter the extensive presence of substitutes in the market. Retaining market share gains paramount importance and as such, this stage is characterized by slowing growth, intense rivalry and declining profitability. Weaker competitors discover that they can no longer generate enough sales or profits to sustain themselves; they sell off their assets, declare bankruptcy or are acquired by stronger competition[13]. Large players survive the shakeout phase by further consolidating their positions either through rapid acquisitions or by capital infusions or both.

Shakeouts are usually triggered by certain events which intensify industry competition and can largely be classified under two heads:

- Boom-and-Bust Syndrome [14] - an unsustainable glut of competitors are attracted to a hot emerging market which eventually exceeds the industry's carrying capacity. As competition intensifies, resources become scare and falling prices exert pressure on margins, many companies begin to fail.

- Seismic-Shift Syndrome [14] - this form of shakeout forces players in an industry enjoying years of protected prosperity to adjust to a fundamental change in their market's rules. Such shifts result from a major change in an industry's technology which makes older technology obsolete or from the emergence of 'competency predators' who have developed a more efficient business model and enter the 


\section{ELK ASIA PACIFIC JOURNAL OF FINANCE AND RISK MANAGEMENT}

ISSN 2349-2325 (Online); DOI: 10.16962/EAPJFRM/issn. 2349-2325/2015; Volume 9 Issue 3 (2018)

industry out of nowhere and grab large shares in markets that welcome the new level of service or sharply reduced costs.

The Boon-and Bust syndrome can be observed in the relatively young ecommerce market in India which emerged in around 2005 with the entry of E-Bay and has since moved swiftly through a rapid growth phase with the market being flooded with numerous players due to attractive margins and high growth prospects. As large players emerging out of the growth phase began the process of fortification of their market positions by pouring in funds and slashing prices, sales and resources of smaller players started sinking and a shakeout became imminent. The industry began showing signs of vertical consolidation as early as 2012 with players adding new categories and support services by acquiring existing players as seen in Flipkart's acquisition of LetsBuy in 2012 to add electronics to its platform, Snapdeal's acquisition of FreeCharge (2015), Flipkart's accquistion of FX Mart (2015) and Amazon's acquisition of Emvantage Payments Pvt Ltd (2016) to add e-wallets to their respective platforms. As vertical consolidations strengthened the operational efficiencies of large players, several weaker players were unable to sustain operations and the industry witnessed numerous exits in recent years including Fashionara (2016), Ladyblush (2016), Kolzee (2016), Overcart (2017) and Abof (2017). While several firms shut down operations, others have been acquired by large players who are looking for horizontal consolidation of their businesses. Examples include Flipkart's acquisition of Myntra in 2014 and Jabong in 2016; and the notable sale of E-Bay to Flipkart in 2017. Even though Flipkart had adopted a rapid acquisition strategy to survive the shakeout phase, it was unable to sustain against its larger competitor Amazon which has been bringing in huge amounts of funding from its US parent to acquire new customers and capture market share[15]. Flipkart was ultimately forced to surrender to the huge fund requirements necessary to survive the shakeout, resulting in the acquisition of a 77\% stake in Flipkart by Walmart[28] - the world's largest company by revenue[29]. The e-commence industry in India is likely to go through a prolonged shakeout phase with the competition poised to get further intense, given the slow and steady entry of Alibaba, the world's largest e-commerce industry, in the Indian online marketplace[16].

A typical example of the Seismic-Shift syndrome is presented by the telecom sector 


\section{ELK ASIA PACIFIC JOURNAL OF FINANCE AND RISK MANAGEMENT}

ISSN 2349-2325 (Online); DOI: 10.16962/EAPJFRM/issn. 2349-2325/2015; Volume 9 Issue 3 (2018)

in India which has been hurled into the consolidation phase with the entry of Reliance Jio in 2016. The telecom industry has for long remained in the transition area between the growth and the shakeout phase with a few large players, such as Airtel, Vodafone and Idea, managing to increase revenue and earnings, even as smaller carriers struggled to make a profit. This phenomenon was witnessed because the telecom industry needed huge investments in infrastructure and spectrum acquisition even as tariffs were among the lowest in the world[17]. However, with Reliance Jio introducing the VoLTE technology in India offering free voice calls and significantly cheaper data tariff plans, the present technology used by existing players was rendered obsolete, triggering intense price wars and heavy marketing spends. As larger players have been sustaining considerable losses to retain market share, survival became difficult for smaller players and as a result, a consolidation wave has swept through the industry over the last 2 years[17]. The most significant merger was witnessed between the 2 industry giants Idea and Vodafone which resulted in their combined market share taking over top space at about 35\%[18]. Former market leader Airtel has entered into acquisition deals with weaker operators Telenor, Videocon, Aircel and Tata Teleservices, bring its market share to almost $26 \%[18]$. Jio has acquired nearly 14\%[18] market share in the short tenure of its operations and is set to further expand its reach with the recent buy-out of Reliance Communications.

As the rapid consolidations in an industry going through its shakeout phase gradually dilutes the number of players, the industry will then move to the mature phase where a select few players dominate the market scenario.

\section{MATURITY STAGE OF THE INDUSTRY LIFE CYCLE}

Post the shakeout stage, the industry consolidates and moves to the maturity stage. Characteristics of an oligopoly begin to emerge and the industry is dominated by a small number of large companies. Competition among the industry giants is intense and market shares are steadily and jealously guarded. Business models are well established and threat of new entrants is low since the market is saturated and there are high barriers to entry. Bargaining power of buyers is at its peak as demand is stagnant and customers are well aware of 


\section{ELK ASIA PACIFIC JOURNAL OF FINANCE AND RISK MANAGEMENT}

ISSN 2349-2325 (Online); DOI: 10.16962/EAPJFRM/issn. 2349-2325/2015; Volume 9 Issue 3 (2018)

the options available and have learnt to choose and differentiate. Products are largely standardized and several product differentiation strategies are adopted to retain customers and maintain brand value. Threat of substitutes begin to emerge and players are focused on building brand loyalty and further improving economies of scale[19].

The carbonated-drinks industry in India has entered its mature stage with its growth pegged at a mere $4 \%$ between 2016-21[20]. The industry is dominated by two major players, PepsiCo and Coca-Cola who hold roughly $60 \%$ of the market share between them. After PepsiCo's entry India in 1989 and Coca-Cola re-entry in 1993, these two rivals have dominated the soft-drink industry for almost three decades and have smartly acquired or smothered domestic and international competitions during earlier phases of the industry's life cycle. The competition among these two players is intense and in order to spur sales of their carbonated-drinks portfolio, the companies have looked to deliver innovation in product, packaging and consumer engagement. Retaining customers and creating brand loyalty has been of utmost importance and both companies have substantially increased their advertising and media investments with Coca Cola's marketing spends alone representing $10 \%$ of its sales in 2016[21]. The extensive brand recognition and economies of scale prevent the threat of new entrants to a large extent; however, the players face strong competition from the presence of substitutes in form of fruit-based and healthier drinks. Coca-Cola and Pepsi have been losing share to local rivals including Parle, Dabur, Hector Beverages and ITC in the soft-drinks segment even as the global giants introduced more fruit-based and healthier products to reduce their reliance on sugary sodas. Between 2014 and 2016, Coca-Cola India's market share has shrunk from about $36 \%$ to $34 \%$ while PepsiCo's has gone down from $23 \%$ to $22 \%[22]$. A pronounced shift in consumer preference for non-sugary healthier beverages has resulted in sluggish demand for colas with the share of carbonated drinks in the beverage segment declining from its peak of $51 \%$ in 2014 to $46 \%$ in 2016. Slow growth has impacted volumes of Coca-Cola and PepsiCo with plants for carbonated drinks running at about half their capacities almost throughout the year[20]. As such, both the companies have been expanding their beverage portfolio into many newer categories in line with evolving consumer 


\section{ELK ASIA PACIFIC JOURNAL OF FINANCE AND RISK MANAGEMENT}

ISSN 2349-2325 (Online); DOI: 10.16962/EAPJFRM/issn. 2349-2325/2015; Volume 9 Issue 3 (2018)

choices including packaged mineral water, a wide range of healthy drinks and very recently, the dairy segment[22].

As market demand gets saturated in the maturity phase resulting in slow growth and declining sale volumes, the players begin entering new businesses to ensure their long-term survival and the industry moves into its decline stage.

\section{DECLINE STAGE OF THE INDUSTRY LIFE CYCLE}

The maturity stage gradually leads to the onset of the decline stage which is characterized by low competition due to unattractiveness of the industry on account of shrinking returns and high barriers to entry. Duration of the maturity stage varies from industry to industry with some enjoying a long period of maturity while others facing an early demise. In the decline stage, only a few players remain and the market leader is clearly visible. The industry players face shrinking demand and technology and product development becomes superfluous. The companies in this stage either expand to other businesses in search of new opportunities or witness diminishing returns ultimately leading to their shutdown.
The cigarette industry in India has entered its declining stage with volumes dropping to a 15-year low in 2016 on account of high taxes, stringent regulations, rising consumer awareness and increase in illicit cigarette trade which caused sales to shrink by $22 \%$ [23]. Only three major players remain in the market scenario, with ITC being the clear market leader with $79 \%$ share, followed by Godfrey Phillips India Ltd (GPI) with $11 \%$ share and VST Industries Ltd at the third position with an 8\% share[24]. The cigarette industry in India has a long history of existence and used to be highly fragmented with several small and medium scale 'beedi' manufactures present in the market since the pre-independence era. ITC has been operating in the tobacco segment since 1910 and the industry entered its growth phase with the entry of the international firm, Godfrey Phillips Ltd in 1968 which spurred industry competition. The industry has since consolidated, with competition either being eliminated or absorbed by the major players, and as such, the industry has now set foot into its decline phase. In this scenario, ITC has responded to the shrinking demand in the cigarette industry by expanding into several other market segments which include food products, 


\section{ELK ASIA PACIFIC JOURNAL OF FINANCE AND RISK MANAGEMENT}

ISSN 2349-2325 (Online); DOI: 10.16962/EAPJFRM/issn. 2349-2325/2015; Volume 9 Issue 3 (2018)

FMCG, stationary, hotels, paperboards packaging and printing and information technology. By lowering its reliance on the cigarette industry, ITC has emerged as one of India's top conglomerates with its cigarette business accounting for only $42 \%$ of its net segment revenue in 2017[25]. Similarly, Godfrey Phillips has also forayed into different market segments including mouth freshener and confectionery to protect its returns. On the other hand, several companies which have survived through the earlier stages of the industry's life-cycle have been unable to diversify their business and with shrinking demand and declining returns, these companies have been incurring heavy losses and face difficulty in carrying on business. GTC Industries, which used to sell cigarettes under once popular brands such as Panama, Chancellor, Esquire and Golden's Gold Flake witnessed the erosion of its net worth in the face of sluggish sales and low returns and was declared as a 'sick company' by BIFR in 2000. Though GTC's net worth has recovered, it has been forced to put up its Mumbai plant for sale in 2017 to pay off long outstanding dues[26]. The Hyderabad Deccan Cigarette Factory, which manufactures cigarettes under the 'Golconda' brand saw robust sales during the 1900s when the tobacco industry was booming in India and there was low incidence of taxes. However, the company witnessed dwindling sales with the passage of time and in 1980, it associated itself with ITC in order to avail funds and machinery for survival[27].

The decline stage is the last stage of the industry life-cycle as the industry loses its attractiveness with shrinking demand and dwindling returns. Firms existing in such industries either expand to other industries for better opportunities or face a slow demise in the existing industry.

\section{CONCLUSION}

According to the theory of industry life cycle, all industries go through five very different phases, where each particular phase requires a strategy that will effectively absorb specific conditions of that phase. The structure of the industry affects the rules of competition, and thus, the necessary strategies for survival and development. Industry competition moves largely in line with the market demand, with rivalry among players being low in the early stages of an industry and gradually gaining momentum in the growth phase. Industry competition reaches its peak during the 


\section{ELK ASIA PACIFIC JOURNAL OF FINANCE AND RISK MANAGEMENT}

ISSN 2349-2325 (Online); DOI: 10.16962/EAPJFRM/issn. 2349-2325/2015; Volume 9 Issue 3 (2018)

Shakeout phase, wherein, weaker players are eliminated and industry giants emerge. The maturity phase continues to witness intense competition among the remaining players, however, the focus shifts from acquiring market share to protecting the existing customer base. With the onset of the decline phase, competition diminishes and shrinking demand and low returns force players to either explore other businesses to ensure survival or perish as they struggle to operate in a declining industry. The industry life-cycle pattern can largely be observed in almost all industries, and a study of where a firm stands in its industry's life-cycle can help it formulate effective business strategies, to ensure long-term growth and survival.

\section{REFERENCES}

[1] Utterback and Abernathy 1975; Utterback and Suarez 1993; Utterback 1994; Klepper 1996,1997; Adner and Levinthal 2001

[2] Gerry Johnson, Kevan Scholes, Richard Whittington, "Exploring Corporate Strategy", 2008

[3] Michael E. Porter, "How Competitive Forces Shape Strategy," May 1979 (Vol. 59, No. 2), pp. 137-145
[4] Graeme K. Deans, Fritz Kroeger, Stefan Zeisel, "The Consolidation Curve", Havard Business Review, December 2002 edition

[5] Pharma Review, 2005

[6] Sun Pharma Press Release, Mumbai, May 25, 2018

[7] Economic Times, "Top five Indian pharma companies together spent over Rs. 8000 crore on R\&D spend in FY17" June 08, 2017

[8] AIOCD AWACS Research Report, March 2016 and March 2018

[9] "The concept of Industry Life Cycle and Development of Business Strategies", Working Paper, University of Zagreb

[10] Counterpoint Research Report, Q2 2018

[11] Economic Times, "How Indian smartphones are losing out to China", May 31, 2017

[12] Scott, David L. (1998). Wall Street Words. Houghton Mifflin

[13] Jeffrey S. Harrison, Foundations in Strategic Management, 3rd Edition 


\section{ELK ASIA PACIFIC JOURNAL OF FINANCE AND RISK MANAGEMENT}

ISSN 2349-2325 (Online); DOI: 10.16962/EAPJFRM/issn. 2349-2325/2015; Volume 9 Issue 3 (2018)

[14] George Day, Harvard Business

Review, Mar-Apr 1997 edition

[15] Economic Times, "Racing against

Flipkart, Amazon pumps record capital into

India" January 29, 2018

[16] Forbes India, "Ecommerce wars: It's Alibaba vs Amazon in India”, December 26, 2017

[17] Livemint.com, "The shakeup in India's telecom sector" October 21, 2017

[18] TRAI Monthly Telecom Subscription Data, December 2017

[19] "Strategic Management and Business Policy" Third Edition, Tata McGraw-Hill Education

[20] Economic Times, "Coca-Cola, PepsiCo hit hard by slow growth in soft drinks segment” August 24, 2017

[21] Motley Fool, LLC "You Wouldn't Believe the Size of Coca-Cola's Advertising Budget” August 27, 2017
[22] Business Today "How Colas lost their mojo", June 04, 2017

[23] Economic Times, "22\% shrinkage in legal cigarette sales in India" January 24, 2017

[24] Euromonitor International, “Cigarettes in India" Oct 2017

[25] ITC Ltd, Annual Report, 2017

[26] DNA India, "GTL puts Mumbai plant on sale for Rs 1,200 crore", November 27, 2017

[27] Times of India, "Badshahs of smoke: History of another bygone Golconda", May 27, 2017

[28] Flipkart.com, 'Team Flipkart stories', May 9, 2018

[29] Fortune Global 500 List, 2018 


\section{LIST OF FIGURES}

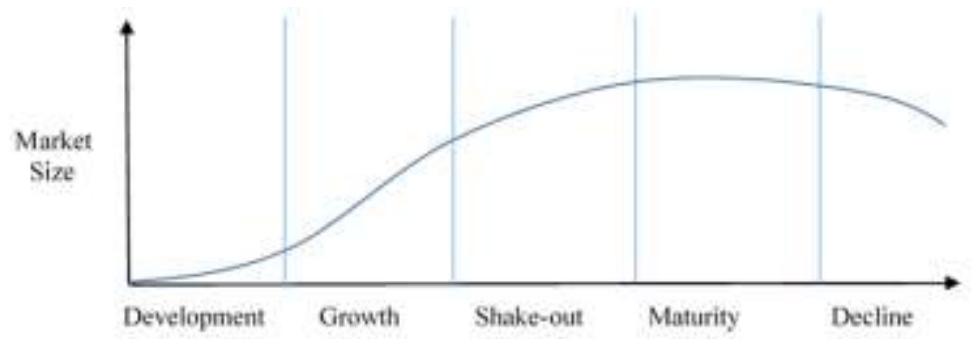

Fig. 1: Stages of the industry life cycle

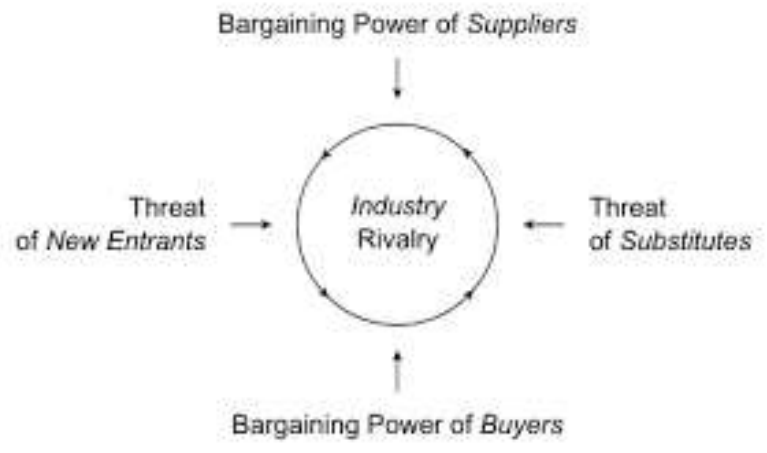

Fig. 2: Porter's Five Forces Framework 